\title{
СКИФСКИЙ КУРГАН № 4 ГРУППЫ «ВОДОВОД» НА ЛЕВОБЕРЕЖЬЕ НИЖНЕГО ДНЕСТРА
}

(C) 2017

Синика Виталий Степанович, кандидат исторических наук, доцент, ведущий научный сотрудник научно-исследовательской лаборатории археологии

Приднестровский государственный университет им. Т.Г. Шевченко (2. Тирасполь, Республика Молдова)

Тельнов Николай Петрович, кандидат исторических наук, доцент, заведующий отделом античной и средневековой археологии

Институт культурного наследия Академии наук Республики Молдова (2. Кишинёв, Республика Молдова)

Закордонец Оксана Александровна, учитель истории

Бендерская средняя общеобразовательная школа № 11 им. Ю.А. Гагарина (2. Бендеры, Республика Молдова)

Аннотация. В статье публикуются материалы, полученные при исследовании скифского кургана 4 группы «Водовод» на левобережье Нижнего Днестра в 2016 г. Основное погребение, ограбленное в древности практически полностью, было окружено кольцевым рвом с двумя разрывами - на северо-западе и юговостоке. У западной оконечности северной дуги рва находился череп лошади. Впускное захоронение в кургане сохранилось непотревоженным. Оно было совершено в вытянутой яме. Подобные сооружения до настоящего времени в Дунай-Днестровских степях не фиксировались, при этом исключение составляет яма аналогичных пропорций, исследованная в кургане 5 того же могильника, что и публикуемый комплекс. Анализ погребального обряда и немногочисленного сохранившегося инвентаря демонстрирует, что оба захоронения принадлежали рядовым общинникам. В то же время золотая обойма и бронзовая серьга из впускного погребения практически не имеют аналогий в скифских комплексах степей Северо-Западного Причерноморья. Гвоздевидная серьга из впускного захоронения свидетельствует о культурном импульсе со стороны населения Среднего Поднестровья (лесостепь), проявившемся в убранстве скифов левобережья Нижнего Днестра во второй половине IV в. до н.э.

Ключевые слова: скифы; IV в. до н.э.; левобережье Нижнего Днестра; степь; погребальный обряд; курган; ров; череп лошади; захоронение; вытянутая яма; материальная культура; золотая обойма; бронзовый наконечник стрелы; бронзовая гвоздевидная серьга; культурный импульс; лесостепь; Западно-Подольская группа; Среднее Поднестровье.

В 2015 г. сотрудниками научно-исследовательской лаборатории «Археология» Приднестровского государственного университета им. Т.Г. Шевченко (г. Тирасполь) было начато исследование курганной группы «Водовод», расположенной в 4 км к северовостоку от западной оконечности с. Глиное Слободзейского района на левобережье Днестра. Исследования были продолжены в 2016 г. За два сезона раскопано пять насыпей, одна из которых была сооружена в раннем бронзовом веке племенами ямной культурной исторической общности, а четыре остальные - в скифское время [1; 3-5]. В настоящей работе публикуется и анализируется курган № 4 группы «Водовод», в ходе исследования которого были изучены ров и два скифских погребения.

Ниже приводится описание кургана, обоих захоронений, погребального инвентаря, а также анализ полученных материалов.

Курган 4 копался параллельными траншеями с использованием техники. Были разбиты три бровки по линии север - юг. Ширина всех бровок по 0,6 м, длина - по 24 м. Расстояние между Западной (данная бровка попала за пределы кургана и не отражена на его плане) и Центральной бровками 4 м, между Центральной и Восточной бровками 3,7 м.

В кургане обнаружены ров и два скифских захоронения (рис. 1, 2-8).

Кольцевой ров диаметром до 14,5 м, шириной до 0,6 м и глубиной до $1-1,1$ м от $\mathrm{R}_{0}$ был сооружён одновременно с основным захоронением 2 . В северозападной и юго-восточной частях рва были оставлены два прохода шириной 3,2 м (на северо-западе) и 2,6 м (на юго-востоке). На дне рва близ перемычек были зафиксированы кости животных и фрагменты керамики. У западной оконечности северной дуги рва на глубине $-1,10$ м от $\mathrm{R}_{0}$ обнаружен череп крупной особи лошади домашней, лежавший на левом боку, мордой на север-северо-восток. Нижняя челюсть отсутствовала. Северо-восточнее во рву было найдено ребро животного (лошадь?). У восточной оконечности северной дуги, у восточной перемычки рва, найден мелкий фрагмент лепной керамики. Южнее западной перемычки, в южной дуге рва, на дне были зафиксированы ребро, сустав ноги и позвонок животного (лошадь?). В восточной оконечности южной дуги рва найдены сустав ноги животного (лошадь?) и фрагмент ручки амфоры (1).

Описание находки.

1. Фрагмент ручки оранжевоглиняной амфоры. Длина фрагмента 64 мм, размеры сечения 33,5$35 \times 17$ мм (рис. 1,1$)$. Тесто хорошо отмучено, без видимых примесей.

Погребение 1 (скифское, впускное) обнаружено под Восточной бровкой, в 2,5 м югу от её центра. Совершено в яме (рис. 2, 1,2).

Яма прямоугольной формы с закруглёнными углами размерами $1,90 \times 0,50$ м и глубиной $-0,80$ м от $\mathrm{R}_{0}$ была ориентирована по линии запад - восток. Костяк взрослого (женщина?) лежал в вытянутом положении на спине, головой на запад. Череп завалился влево, руки вытянуты вдоль тела.

В заполнении черепа найдена обойма из золотой фольги (2), в районе стоп, в кротовине - бронзовая серьга (3). В заполнении ямы обнаружен фрагмент ручки амфоры (1). 

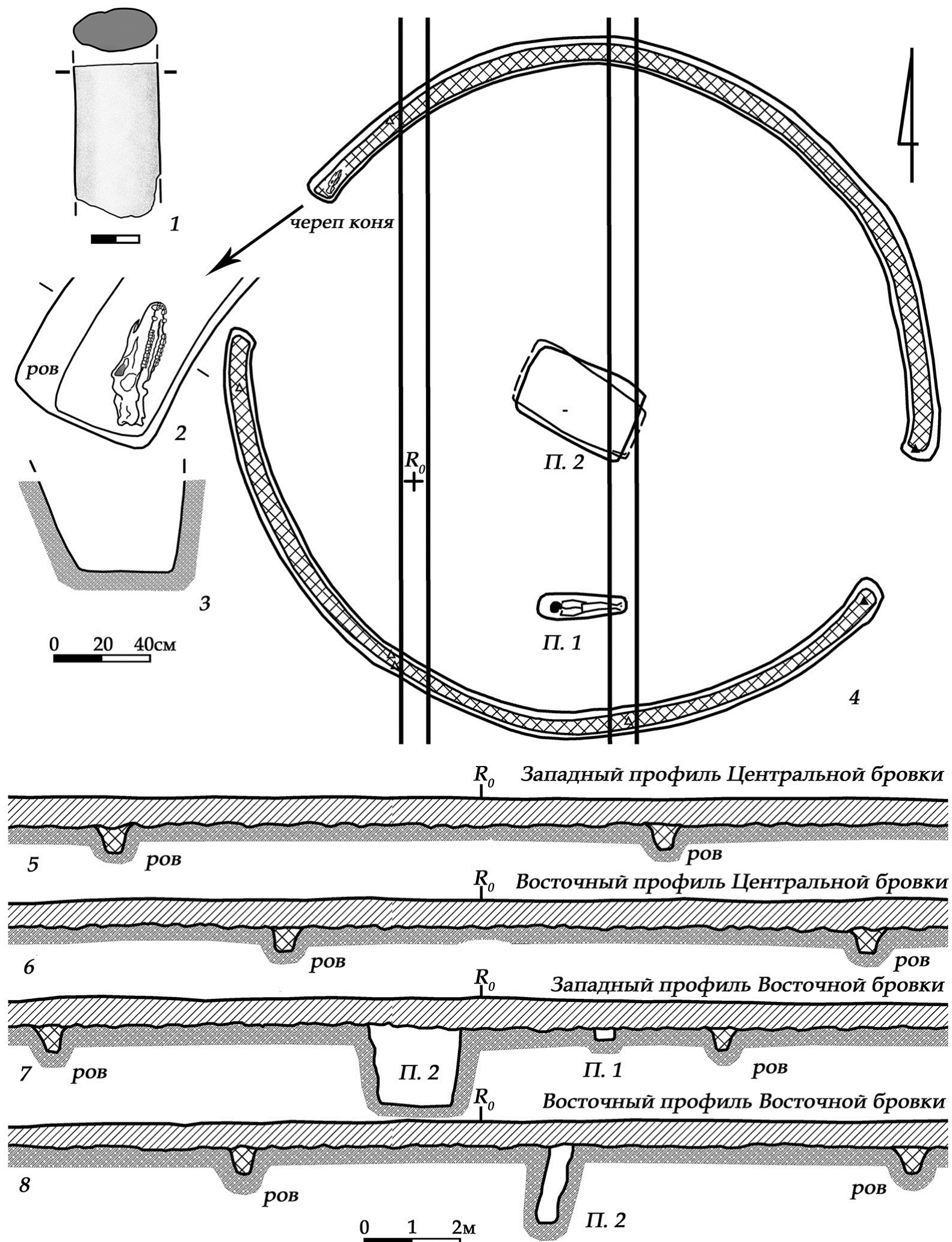

Рисунок 1 - Ручка амфоры изо рва (1), план (2) и разрез (3) западной оконечности северной дуги рва, план (4) и профили бровок (5-8) кургана 4 группы «Водовод»

Описание находок.

1. Фрагмент ручки оранжевоглиняной амфоры. Длина фрагмента 25 мм; размеры сечения $30 \times 27$ мм (рис. 2, 5). Тесто хорошо отмучено, без видимых примесей.

2. Фрагмент обоймы золотой. Размеры $11,4 \times 4,6$ мм, толщина 0,1 мм (рис. 2, 4).

3. Серьга-подвеска бронзовая (в двух фрагментах) с грибовидными окончаниями разного диаметра.
Большой щиток дисковидный, с загнутыми вниз концами и круглым вдавлением в центре. Диаметр 14,5 мм; общая высота шляпки 3 мм; толщина пластины 0,8 мм; диаметр вдавления в центре 2 мм. Маленький щиток грибовидный, дуговидный в сечении. Диаметр 7×8 мм; общая высота шляпки 5 мм; толщина пластины 0,5 мм. Проволока дужки круглая в сечении. Диаметр 1,3-2 мм (рис. 2, 3). 


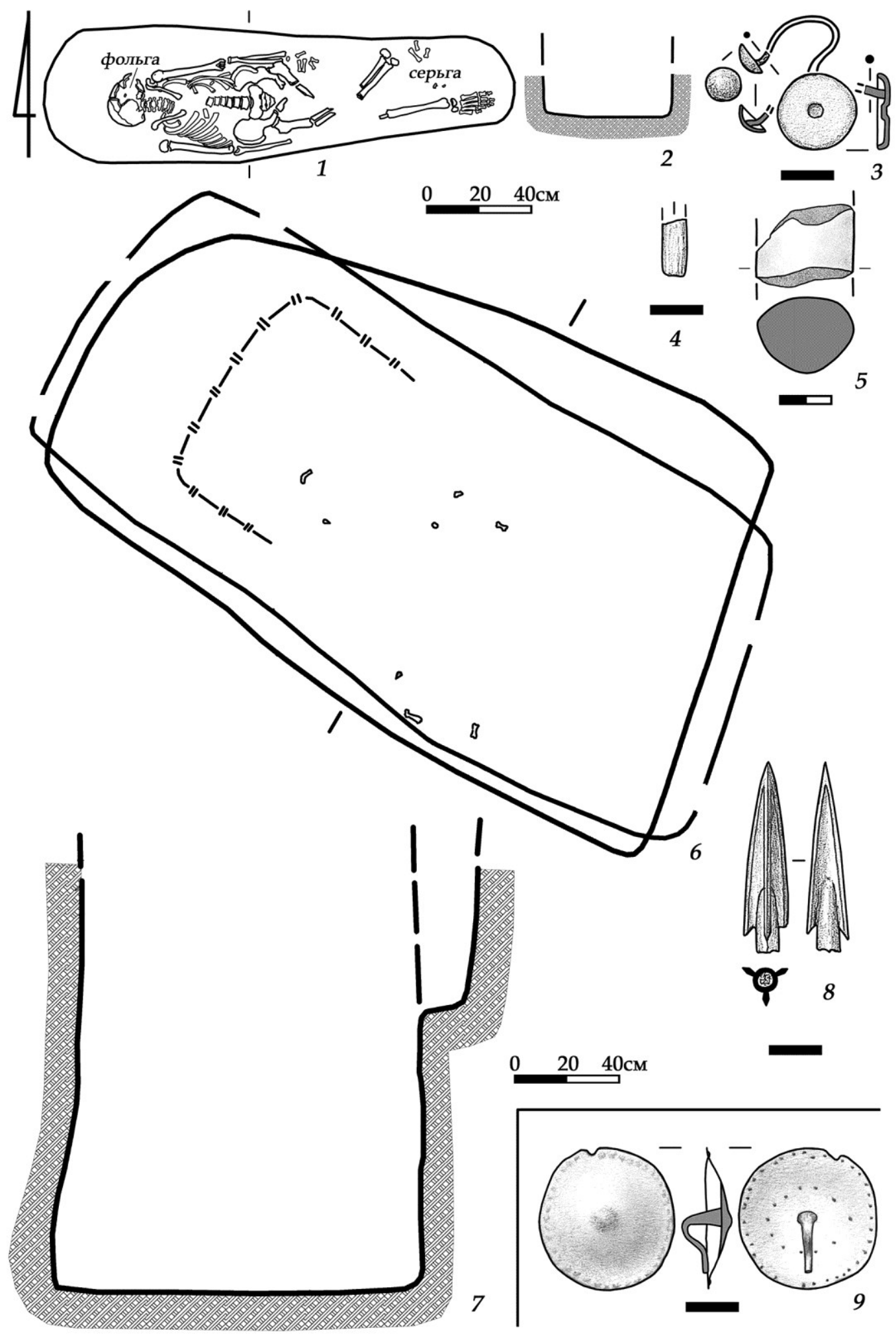

Рисунок 2 - Погребения 1 (1-5) и 2 (6-8) кургана 4 группы «Водовод»; серьга из Токмазеи (9)

Погребение 2 (основное, скифское) обнаружено под восточной бровкой, в 0,5 м к северу от её центра. Совершено в яме (рис. 2, 6, 7).

Яма прямоугольной формы размерами $1,70 \times 1,40$ м и глубиной $-2,13$ м от $\mathrm{R}_{0}$ была ориентирована по линии северо-запад - юго-восток. Погребение ограблено. Северная стенка нарушена грабительским ходом. В заполнении встречались фрагменты костей животных и человека. В южном углу в придонном заполнении (на глубине $-1,85$ м от $\mathrm{R}_{0}$ ) найдена бедренная кость взрослого человека, вплотную к ней лежал бронзовый трёхлопастный наконечник стрелы
(1). На дне ямы в её северо-западной части зафиксирован светло-серый органический тлен от подстилки, мелкие фрагменты костей человека.

Описание находки.

1. Наконечник стрелы бронзовый, трёхлопастный, с выделенной втулкой. Длина наконечника 36,5 мм, длина втулки до 13 мм, диаметр втулки 4,5-5 мм. Во втулке сохранились остатки древка (рис. 2,8 ).

При анализе полученных материалов необходимо констатировать, что основное погребение кургана 4 было ограблено. Впрочем, явление это совершенно 
Синика В.С., Тельнов Н.П., Закордонец О.А.

обычное для скифских курганов Северного Причерноморья. В частности, все основные захоронения скифских курганов (№№ 1, 3, 5) группы «Водовод», в которую входил публикуемый комплекс, были ограблены в древности.

Основное погребение кургана было совершено в прямоугольной яме, на дне которой зафиксированы следы от подстилки. Оба эти элемента обряда наиболее характерны для скифских захоронений VI-IV вв. до н.э. Северо-Западного Причерноморья [6, с. 12 $13,18]$. При этом обращает на себя внимание отклонение длинной оси ямы от строгой широтной ориентировки. В нашем случае она была ориентирована по линии северо-запад - юго-восток. Традиционно подобные отклонения считаются сезонными [7], однако подобная интерпретация вряд ли может считаться исчерпывающей в нашем случае. Заметим, что на одной линии (северо-запад - юго-восток) находилась не только длинная ось основного погребения кургана 4 группы «Водовод», но и оба разрыва его рва.

По всей видимости, в захоронении 4/2 погребённый лежал головой в западном направлении. На это указывает находка бедренной кости взрослого человека в южном углу ямы, а также ориентировка впускного захоронения в яме, ориентированной строго широтно, с погребённым, лежавшим головой на запад.

Впускное захоронение в кургане (4/1) было совершено в вытянутой прямоугольной яме, длина которой в 3,8 раза превосходит ширину. В своё время В.С. Ольховский выделил такие ямы в особый III тип, отметив его редкость (5,2\% от общего числа сооружений подобного вида) у скифов Северного Причерноморья. Исследователь указал, что вытянутые ямы получили наибольшее распространение на Елизаветовском курганном могильнике $(76,4 \%)$ в Нижнем Подонье, а также на грунтовом могильнике у с. Фронтовое $(20,5 \%)$ в Крыму [8, с. 23-24]. Отметим, что ранее подобные ямы в Северо-Западном Причерноморье известны не были. Единственное аналогичное сооружение, прямоугольная яма, длина которой в 4,11 раза превосходит длину, было зафиксировано в 2016 г. в кургане 5, входившем в ту же группу «Водовод» и располагавшемся в 77 м к югуюго-западу от публикуемого в настоящей работе кургана, было исследовано впускное погребение 8 , длина которого составляла 1,85 м при ширине 0,45 м (раскопки авторов; материал в настоящее время не опубликован).

Следует отметить размещение черепа лошади у западной конечности северной дуги рва кургана 4 группы «Водовод». Подобный обряд нередко фиксируется в скифских курганах Северо-Западного Причерноморья. Так, в кургане 6 могильника Владычень (Болградский р-н Одесской обл. Украины) на левобережье Нижнего Дуная череп лошади был зафиксирован ближе к восточной оконечности южной дуги рва, в то время как кости её конечностей находились ближе к восточной оконечности северной дуги рва $[9$, с. 5 , рис. 7,1$]$. На основании наконечников стрел из колчанного набора основное и единственное погребение в кургане датируется первой половиной $\mathrm{V}$ в. до н.э. В конце этого столетия был возведён курган 28 у с. Плавни (между сс. Нагорное и Плавни Ренийского р-на Одесской обл. Украины), во рву которого были найдены лежавшие не в анатомическом Скифский курган № 4 группы «Водовод» на левобережье..

порядке скелеты лошадей $[10$, с. 70 , рис. 27,1$]$. Во рву кургана Цыганка (возле с. Плавни), сооружённом в 60-х гг. IV в. до н.э. [11, с. 185], у перемычки были обнаружены кости ног и черепа лошади [12, с. 103]. Наконец, не позднее третьей четверти IV в. до н.э. был сооружён курган 13 могильника Владычень, у западной оконечности северной дуги рва которого были обнаружены череп и кости конечностей лошади [9, с. 17-18, рис. $19,2,3,5]$.

Известны находки черепов лошадей и в скифских курганах левобережья Нижнего Днестра. В последней четверти V в. до н.э. было совершено основное погребение в кургане 2 у с. Никольское [11, с. 171173]. Это захоронение было окружено рвом, возле северо-западной перемычки которого, у западных окончаний северной и южной его дуг, находились 12 черепов лошадей $[13$, с. 35 , рис. 8$]$. Неполный скелет лошади, в том числе и череп, лежавшие в анатомическом порядке у западной оконечности южной дуги рва, зафиксированы в кургане 21 Дубоссарского могильника, возведённом во второй четверти IV в. до н.э. [11, с. 93, 215, рис. 78].

Таким образом, анализ данных о погребальном обряде свидетельствует о том, что все его составляющие находят аналогии в скифских комплексах $\mathrm{Ce}$ веро-Западного Причерноморья. Без сомнения, курган 4 группы «Водовод» был сооружён для захоронения рядовых общинников. Об этом свидетельствует и погребальный инвентарь, представленный всего тремя находками, поскольку основное захоронения кургана было ограблено практически полностью.

Вместе с тем необходимо отметить, что оба изделия из сохранившегося непотревоженным впускного погребения 4/1 практически не имеют аналогий в скифских комплексах Северо-Западного Причерноморья в целом и Поднестровья в частности.

Фрагмент золотой обоймы из этого захоронения, обнаруженный внутри черепа, вероятно, являлся частью наконечника шнурка, фиксировавшего волосы погребённого либо края несохранившегося головного убора. Такие металлические обоймы (шнурков?) в скифских погребальных памятниках VI-IV вв. до н.э. авторам настоящей работы неизвестны. Единственной сколько-нибудь близкой параллелью являются бусины от «налобных повязок», зафиксированные справа и слева у черепа (у висков), а также на черепе погребённых в 18 захоронениях (девяти мужских, шести женских, трёх детских) скифского могильника III-II вв. до н.э. у с. Глиное Слободзейского района $[14$, c. 871$]$. Примечательно, что северная оконечность данного могильника расположена в 2,3 км к юго-западу от курганной группы «Водовод».

Бронзовая серьга из погребения 4/1 группы «Водовод», сохранившаяся в двух фрагментах, относится к 1 варианту (со шляпкой меньшего размера на окончании) 1 типа (серьги с округлым щитком, напоминающим по форме шляпку гриба) по классификации В.Г. Петренко. Исследователем были учтены 23 подобные серьги, 12 из которых происходят из Днепровского Правобережья, семь - из Западной Подолии, три - из Посулья, и одна - из бассейна р. Ворскла. При этом было отмечено, что в ЗападноПодольской группе памятников такие серьги встречаются в курганах в три раза чаще, чем на Правобережье Днепра и в Посулье. Датировка данного типа 
серёг была ограничена VI в. до н.э. $[15$, с. 21 , табл. $16,1-13]$. В более поздних исследованиях бытование этих гвоздевидных украшений стало определяться значительно более широким интервалом времени (VII-V вв. до н.э.), а ареал их распространения был существенно расширен, в основном за счёт находок в кремациях лужицкой культуры на территории Польши. Эти находки, равно как и аналогичные изделия из Чехии, Венгрии, Словакии и Белоруссии, отличаются от найденных в украинской Лесостепи наличием полукруглых конусов на одном или обоих концах дужки [16, с. 356, 358-359; 17, с. 148].

Наблюдение Б. Полит относительно того, что большинство гвоздевидных серёг происходит из захоронений рядовых общинников (лиц с невысоким социальным статусом) [16, с. 357], наглядно иллюстрируется погребением 4/1 группы «Водовод». Отмечалось также, что находки одной серьги характерны для мужских захоронений [16, с. 357]. Косвенно об этом свидетельствует и золотая обойма наконечника шнурка, если она действительно принадлежала «налобной повязке». Такие «повязки», как было упомянуто выше, чаще встречаются в мужских захоронениях скифского могильника III-II вв. до н.э. у с. Глиное. Впрочем, без заключения специалистаантрополога, которым мы в настоящее время не располагаем, наши суждения о половой принадлежности погребённого из захоронения 4/1 группы «Водовод» носят весьма условный характер.

Как уже было показано, ранее в степях Северного Причерноморья серёг, подобных изделию из погребения 4/1 группы «Водовод», не отмечалось. Вместе с тем, именно здесь, на левобережье Нижнего Днестра, в 2016 г. было обнаружено ещё одно аналогичное украшение. Предмет был найден на берегу p. Днестр возле с. Токмазея Григориопольского района, в 43,85 км (по прямой линии) к северо-западу от курганной группы «Водовод». Он представляет собой гвоздевидную серьгу (диаметр конической шляпки 27 мм), дужка которой, после того как сломалась, была согнута в виде петли: не исключено, что эта серьга могла использоваться вторично как бляшка конской узды (рис. 2, 9). И если находка из Токмазеи представляет собой типичный образец гвоздевидных серёг, аналогичный найденным на памятниках украинской Лесостепи, а значит, дату их производства можно определять VII-V вв. до н.э., то находка из кургана 4 группы «Водовод» с нехарактерным для таких украшений вдавлением в центре щитка не может датироваться даже V в. до н.э., не говоря уже о более раннем времени.

Для определения времени сооружения кургана 4 группы «Водовод», за неимением более надёжных хроноиндикаторов, мы вынуждены опираться на бронзовый наконечник стрелы из основного в кургане погребения. Подобные наконечники (трёхлопастные, с подтреугольной головкой и со слегка выделенной втулкой), в частности, были найдены (68 экз.) в погребении 2/12 группы «Водовод», совершённом на рубеже третьей - последней четверти IV в. до н.э. [5]. Ещё два подобных наконечника стрел были обнаружены в погребении 3/2 группы «Водовод» рубежа IV-III вв. до н.э. [1, с. 262, 265, рис. $2,11,12]$. Таким образом, у нас есть все основания датировать курган 4 группы «Водовод» не шире, чем в пределах второй половины IV в. до н.э.
В этой связи в настоящее время можно констатировать, что гвоздевидные серьги продолжали бытовать и в IV в. до н.э., пусть и в виде реплик более ранних образцов, о чём свидетельствуют материалы кургана 4 группы «Водовод» на левобережье Нижнего Днестра. По всей видимости, традиция ношения таких украшений была заимствована скифами Нижнего (степного) Поднестровья у населения (с выраженным скифским компонентом в погребальном обряде и материальной культуре), оставившего Западно-Подольскую группу памятников. Её ареал охватывает правобережное и левобережное Среднее Поднестровье, а датировка, согласно современным представлениям, - середину VII - начало V в. до н.э. $[18$, с. 75,78 , рис. 1]. Самые южные из известных на данный момент памятников Западно-Подольской группы (у сс. Непоротово и Белоусовка Сокирянского р-на Черновицкой обл. Украины) расположены в 280 км к северо-западу от с. Глиное Слободзейского района (возле которого был исследован курган 4 группы «Водовод») и в 190 км к северо-западу от ландшафтной границы лесостепи и степи на левобережье Нижнего Днестра. С учётом этого, расстояние менее чем в 100 км между границей лесостепи и степи и курганом 4 группы «Водовод» и менее чем в 50 км между указанной границей и упомянутой выше находкой серьги из Токмазеи не было непреодолимым для лесостепного культурного импульса, одним из свидетельств которого являются гвоздевидные серьги. Тем более что путём его распространения являлась природная артерия в виде р. Днестр, в бассейне которой расположены как памятники Западно-Подольской группы (Среднее Поднестровье), так и находки из Токмазеи и кургана 4 группы «Водовод» (Нижнее Поднестровье). Дополнительным и весьма весомым аргументом в пользу межкультурного взаимодействия скифского населения Среднего (лесостепного) и Нижнего (степного) Поднестровья являются сожжённые деревянные гробницы, исследованные в степях Поднестровья [11, с. 189-191, рис. 145].

В завершении необходимо отметить, что материалы, полученные при исследовании кургана 4 группы «Водовод», возведённого во второй половине IV в. до н.э., не только свидетельствуют о культурных влияниях населения лесостепи на скифов степного левобережного Поднестровья в указанное время, но и имеют самое прямое отношение к проблеме непрерывного присутствия скифского населения в данном регионе в IV-II вв. до н.э.

С одной стороны, в 2012 г. были завершены исследования скифского могильника III-II вВ. до н.э. у с. Глиное Слободзейского района, в составе которого нет курганов второй половины IV в. до н.э. [14, c. 965]. С другой стороны, в составе курганных групп «Сад» [19] и «Водовод» $[1 ; 2 ; 4 ; 5]$, расположенных в непосредственной близости от этого могильника, в ходе раскопок 2015-2016 гг. были зафиксированы скифские захоронения, дата которых не выходит за пределы IV в. до н.э. И хотя исследование различных курганных групп у с. Глиное Слободзейского района ещё далеко от завершения, уже в настоящее время вопрос о существовании хронологической «лакуны», в частности, в пределах III в. до н.э., в исторической картине степей Нижнего Поднестровья можно считать закрытым. 
Синика В.С., Тельнов Н.П., Закордонец О.А.

\section{СПИСОК ЛИТЕРАТУРЫ:}

1. Синика В.С., Тельнов Н.П. Скифский курган № 1 группы «Водовод» на левобережье Нижнего Днестра // Емінак, 2016. № 4 (16). С. 45-53.

2. Синика В.С., Тельнов Н.П. Скифское захоронение с тамгой рубежа IV-III вв. до н.э. с левобережья Нижнего Днестра // Новое прошлое, 2016. № 4. C. $258-272$

3. Панковский В.Б., Синика В.С. Роговой гребень из скифского погребения у с. Глиное // Stratum plus. 2017. № 3. С. 343-359.

4. Синика В.С., Тельнов Н.П. Скифское погребение с уникальным амулетом с левобережья Нижнего Днестра // Научные ведомости БелГУ. Сер. История. Политология, 2017. № 8 (257), Вып. 42.

5. Синика В.С., Тельнов Н.П. Скифское погребение с фракийской фибулой на Нижнем Днестре // Stratum plus, 2017. № 3. C. 131-152.

6. Синика В.С. Погребальные памятники скифской культуры VII - начала III в. до н.э. на территории Днестро-Прутско-Дунайских степей: автореф. дис. ... канд. ист. наук. М., 2007. 28 с.

7. Генинг В.В., Генинг В.Ф. Метод определений древних традиций ориентировок погребённых по сторонам света // Археология и методы археологических реконструкций. К.: Наукова думка, 1985. C. $136-152$

8. Ольховский В.С. Погребально-поминальная обрядность населения степной Скифии (VII-III вв. до н.э.). М.: Наука, 1991. 256 с.

9. Фокеев М.М. Отчёт о раскопках Владыченьской экспедиции: могильник Владычень 1. Архив ИА НАНУ. № 1989/51. К., 1990.

10. Андрух С.И., Добролюбский А.О., Тощев Г.Н. Курганы у села Плавни в низовьях Дуная: монография депонирована в ИНИОН АН СССР 13.06.1985 г., № 21110. Одесса, 1985.158 c.
11. Кетрару Н.А., Синика В.С., Разумов С.Н., Тельнов Н.П. Дубоссарские курганы (Археологические памятники Приднестровья, II). Тирасполь: Stratum plus. 2014. $240 \mathrm{c}$.

12. Ольховский В.С., Шилов Ю.А. Скифский погребально-культовый комплекс кургана Цыганка // PA, 1995. № 4. C. 103-113.

13. Агульников С., Сава Е. Исследования курганов на левобережье Днестра. Кишинёв. CEP USM, 2004. $243 \mathrm{c}$.

14. Тельнов Н.П., Четвериков И.А., Синика В.С. Скифский могильник III-II вв. до н.э. у с. Глиное (Археологические памятники Приднестровья, III). Тирасполь: Stratum plus, 2016. 1096 с.

15. Петренко В.Г. Украшения Скифии VII-III вв. до н.э. (Свод археологических источников. Вып. Д45.). $144 \mathrm{c}$.

16. Полит Б. Гвоздевидные серьги с территории Украины и Польши // Боспорские чтения. Вып. XI. C. $356-362$.

17. Політ Б. Матеріали до вивчення цвяхоподібних сережок ранньозалізного віку з території Польщі // Археологічні дослідження Львівського університету, 2010. Вип. 13. С. 148-170.

18. Смирнова Г.И. Западно-Подольская группа раннескифских памятников в свете исследований к концу XX столетия // Древности скифской эпохи: мат-лы и исследования по археологии России, № 7. М.: Институт археологии РАН, 2006. С. 66-92.

19. Синика В.С., Тельнов Н.П. Скифское погребение с литиком-скарабеоидом с левобережья Нижнего Днестра // Стародавнє Причорномор'я. Вип. ХI (голов. ред. І.В. Нємченко). Одеса: Одеський національний університет імені I.I. Мечникова, 2016. C. $488-499$.

\section{SCYTHIAN BARROW № 4 OF THE «SLUICEWAY» GROUP ON THE LEFT BANK OF THE LOWER DNIESTER}

(C) 2017

Sinika Vitalij Stepanovich, candidate of historical sciences, associate professor, leading researcher of Archaeology Scientific Laboratory Pridnestrovian State University (Tiraspol, Republic of Moldova)

Telnov Nikolai Petrovich, candidate of historical sciences, associate professor, head of Antique and Medieval Archeology Department Institute of Cultural Heritage of Academy of Sciences of Moldova (Kishinev, Republic of Moldova) Zakordonets Oksana Alexandrovna, teacher of history Bendery Secondary School №11 named after Yu.A. Gagarin (Bendery, Republic of Moldova)

Abstract. The paper publishes materials obtained during the study of Scythian barrow 4 of the «Sluiceway» group on the left bank of the Lower Dniester in 2016. The main burial, almost completely robbed in antiquity, was surrounded by a ring ditch with two ruptures - in the northwest and southeast. At the western extremity of the northern arch of the ditch a horse's skull was found. Secondary burial of the barrow remained undisturbed. It was done in an oblong pit. Such constructions have not been fixed in the Danube-Dniester steppes so far, except for a pit of similar proportions, excavated in the barrow 5 of the same cemetery as the published complex. The analysis of the funeral rite and a few preserved inventories demonstrates that both burials belonged to ordinary members of the Scythian community. At the same time, the gold holder and bronze earring from the secondary burial have practically no analogies in the Scythian complexes of the steppes of the North-Western Black Sea Region. A nail-shaped earring from the secondary grave testifies to the cultural impulse from the population of the Middle Dniester Region (foreststeppe), reflected in the finery of the Scythians on the left bank of the Lower Dniester in the second half of the 4th century BC.

Keywords: Scythians; 4th century BC; left bank of Lower Dniester; steppe; funeral rite; barrow; ditch; horse's skull; burial; oblong pit; material culture; gold holder; bronze arrowhead; bronze nail-shaped earring; cultural impulse; forest-steppe; West-Podolian group; Middle Dniester Region. 